\title{
Editorial
}

\section{Lessons from cholera in Haiti}

Journal of Public Health Policy (2014) 35, I35-I36. doi:I0.1057/jphp.20I4.5; published online 6 March 2014

Following the cholera outbreak in Haiti is a little like recapitulating the history of public health. The earliest public health interventions that protected lives were really very simple to understand, if not to implement: keeping food and drinking water clean, reducing crowding in housing, and managing disposal of human waste. Almost two centuries ago, reformers in Europe, then in North America, found that these measures to combat filth were effective. Thus, health improved even before vaccines and antibiotics arrived.

Late in the nineteenth century came scientific knowledge of causal agents, making it possible to blame carriers, often the very same people who lived with filth. The focus for interventions shifted from communities to individuals, from cleaning up environments and creating infrastructure to vaccines and antibiotics.

Where does Haiti fit in this picture? The country has always lacked clean water and proper sewers and then the earthquake of 2010 further damaged the already scant infrastructure. An outbreak in Haiti awaited only the introduction of a communicable pathogen, in this case Vibrio cholerae, rather like a parched landscape awaiting a lit match.

What followed was an outbreak that has taken over 8000 lives and infected almost 700000 more Haitians. How did cholera get to Haiti? In the old days, the health authorities might have found the physical source, like the Broad Street pump, but today, more could be learned. Genetic typing made it possible to recognize that the strain of cholera afflicting Haiti came from Asia, most likely brought to the island by Nepalese soldiers working with the United Nations emergency response for the earthquake.

Very interesting, a triumph for laboratory methods that typed the pathogen! But how cholera got to Haiti offered little help in ending the outbreak or preventing future ones once the disease was spreading. The source didn't much matter. Haiti's abysmal sanitation infrastructure meant that Vibrio cholerae introduced from almost any source could 
have caused an epidemic. To their credit, the Haitian Ministry of Health and the National Directorate for Water Supply and Sanitation, understood how to control and prevent cholera. As stated in $20 \mathrm{II}$ by the United Nations' Independent Panel.

To prevent the spread of cholera, the United Nations and the Government of Haiti should prioritize investment in piped, treated drinking water supplies and improved sanitation throughout Haiti. Until such time as water supply and sanitation infrastructure is established:

(a) Programs to treat water at the household or community level with chlorine or other effective systems, hand washing with soap, and safe disposal of fecal waste should be developed and/or expanded; and,

(b) Safe drinking water supplies should continue to be delivered and fecal waste should be collected and safely disposed of in areas of high population density, such as the spontaneous settlement camps.

As far as we can see, the key lesson from Haiti is that populations around the world that live without potable water and proper management of human fecal waste remain vulnerable. The fact that there had been no cholera in Haiti for over Ioo years should have been no comfort - especially to those in public health who (should) know that protection depends on infrastructure.

In I99I, Dr Robert Knouss, who was serving as the Deputy Director General of the Pan American Health Organization, appeared before a committee of the US Congress to testify about the cholera epidemic in Peru. 'What would it cost to eliminate cholera in the Americas?' he was asked. He had not prepared for just that question, but his answer was quick if not precise: ' $\$ 25$ billion. Enough to build modern drinking water and sewage systems for every major city in the region that lacks one today'. (The number would be far larger in today's dollars.)

We urge the United Nations and programs that contribute money to build infrastructure to learn a lesson from Haiti and think as the late Dr Knouss did. Invest now before you can be 'surprised' by an epidemic of cholera or other waterborne disease from any source.

Anthony Robbins Co-Editor

I36 (C) 20I4 Macmillan Publishers Ltd. OI97-5897 Journal of Public Health Policy Vol. 35, 2, I35-I36 